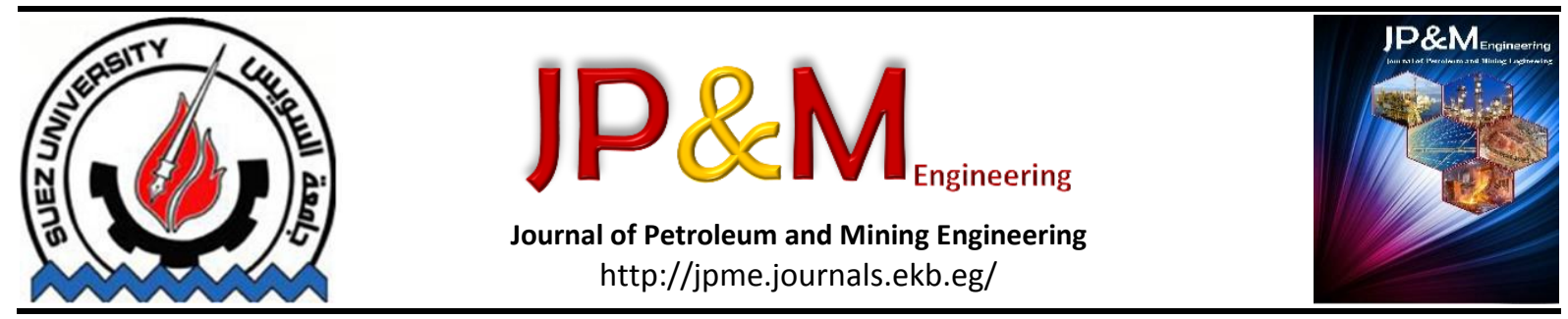

\title{
Well control during drilling and workover operations
}

\author{
Ahmed Elgibaly \\ Petroleum Engineering Dept. Faculty of Petroleum and Mining Enigineering- Suez University- Egypt
}

\begin{abstract}
Kick can occur during drilling or workover operations, since it can easily develop into a blowout even the most simple blowout situation can result in the loss of millions of dollars in equipment and valuable natural resources.

This research study different killing methods in different situations during drilling and workover operations and the factors that affecting killing procedures. The developed study based on actual field cases in different oil fields and results of DRLLSIM 5000 simulator runs for studying factors affecting killing operations.

This study enables to differentiate conventional and non-conventional killing procedures during drilling and workover operations and introduce new drilling technique to face combination of pipe sticking, complete loss of circulations and kick problems while drilling operations and introduce solutions to prevent blow out while drilling shallow gas formations especially in Egyptian western desert and best killing procedures for production gas wells.
\end{abstract}

\section{Keywords}

influx; well control; drilling; workover; simulator.

\section{Introduction}

Well control problems and blowouts are not particular. They occur in the operations of the very largest companies as well as the very smallest. They occur in the most complex operations such as deep, high-pressure gas wells, and they occur in the simplest shallow operations.

By studying the different reasons that causes kicks also kicks warning signs, studying the different methods of shutting in the well, studying the factors that affects killing operations and studying actual well control field cases, finally we can reach to the best method to control the well during drilling and workover operations.

\section{Materials and Methods}

\section{Well control philosophy}

Primary well control

To prevent the kick an overbalance of hydrostatic pressure over formation pressure is maintained this is called trip margin ${ }^{1}$.

\section{Secndary well control}

First stage is shutting in the well using BOP to minimize size of influx and prevent influx escaping from well to surface ${ }^{1}$.
Second stage is killing operations to remove the influx from the well without surface, subsurface and underground blowout ${ }^{1}$.

\section{Tertiary well control}

When the formations cannot controlled by primary and secondary well control and underground blowout and drilling relief wells can be absolutions To save human life and environment due to surface blowout ${ }^{1}$. So good selection of killing procedures in drilling and workover operations is very important to prevent all type of blowouts.

\section{Conventional Kick Circulation Techniques}

\section{Driller's Method}

In the Driller's Method, the kick is circulated out of the hole using the existing mud weight. The mud weight is then raised to the required level and circulated around the well. Two complete circulations are thus required, as a minimum, for this method. The annular pressures produced during the first circulation are higher than produced with any other method $^{2}$.

\section{Wait and Weight}

The "Wait and Weight" is sometimes referred to as the "Engineer's method" or the "One circulation method". It does, at least in theory, kill the well in one 
circulation. Once the well is shut-in and pressures stabilized, the shut-in drill pipe pressure is used to calculate the kill mud weight. Mud of the required weight is made up in the mud pits. When ready, kill mud is pumped down the drill pipe.

With kill mud at the bit, the static head of mud in the drill pipe balances formation pressure. For the remainder of the circulation, as the influx is pumped to the surface, followed by drill pipe contents and the kill mud, the drill pipe pressure is held at the final circulating pressure by choke adjustment ${ }^{3}$.

\section{Concurent Method}

The Concurrent Method is a combination of the Driller's method and the Wait and Weight method. The crew starts to circulate the kick out of the well immediately, using the original mud weight ${ }^{4}$. The Concurrent method is a way of gradually increasing the mud weight while circulating out the kick ${ }^{5}$. The rate of increase will depend on the mixing facilities available on the rig ${ }^{1}$.

The complication here is that the drill pipe can be filled with fluids of different densities, making calculation of the bottom well hydrostatic pressure difficult. However, provided adequate supervision is available on the rig this could be the most effective way of killing a kick. Procedures for Concurrent method are as the following. When all the kick information has been recorded, open up the pump slowly while adjusting the choke until the initial circulating pressure has been reached at the reduced circulating rate $^{6}$.

\section{Non-conventional kick circulation techniques}

\section{Reverse Circulation Method}

Reverse circulating is common practice in routine completion/workover operations primarily because: there is typically less circulating time when circulating "bottoms up", and the fluid velocity up the tubing at any pump rate is much higher than the annular velocity would be at the same rate. Therefore, cleanout capabilities are enhanced7.

\section{Dynamic Kill Technique}

This type of procedure uses friction pressures to its advantage. The principle is to pump fluids at higher rates, so that the high annular friction pressures increase the ECD, hence bringing the well back to a balanced situation ${ }^{8}$.

\section{Bullheading}

This procedure is sometimes called deadheading, and is based on pumping the fluids back down into the well with enough force to reverse the flow, and prevent the kick from reaching the surface ${ }^{8}$. the technique is most often used in cased holes, and it is very simple to perform. Although it is not recommended for drilling operations, as it might actually cause greater harm than good, there are instances where it might be useful to bullhead in the drilling phase ${ }^{9}$.

\section{Volumetric Method}

The Volumetric Method is not a kill method, but rather it is a method of controlling the down hole and surface pressures until kill procedures can be started. It can be used to bring the influx to surface providing no additional influx is allowed. The volumetric principle can also be used to replace the gas with liquid in order to bring the well back under control ${ }^{11,12}$

\section{Lubricate and Bleed Method}

Lubricate and Bleed Method is an application of the Volumetric Method and is used to safely remove gas at the surface when it is not possible or practical to circulate the gas out. In the Lubricate and Bleed Method, liquid is pumped into the well and allowed to fall down through the gas into the annulus. Sufficient time must be allowed for the liquid to fall through the gas, thus increasing the annular hydrostatic pressure. Once the annular hydrostatic pressure is increased as a result of the pumped liquid, casing pressure may be reduced by that value ${ }^{12}$.

The operation entails pumping a carefully measured volume of liquid into the well. The height of the pumped liquid is determined, and then converted to hydrostatic pressure. This value will subsequently be bled off on surface 12 .

\section{Staging the Hole or Top Kill}

An example of a method that is most commonly used when the pipe is off-bottom, is staging the hole. This method aims to place a calculated volume of heavy mud on top of the original mud, thus creating added hydrostatic pressure in a well where the pipe is above the kick $^{11}$

This practice is not often recommended as many complications may occur ${ }^{8}$. One risk is that of the kick migrating and displacing fluids. This would complicate the process severely. If any indication of kick migration is detected, staging in the hole should not be considered10.

\section{Mud Cap Drilling}

In general, good operating practice calls for regaining circulation before drilling ahead. However, in Saudi Aramco drilling operations there is one notable exception, mud-cap drilling. Mud-cap drilling permits continued drilling despite the presence of a pressured formation and a lost-circulation zone in the same interval of open hole. Although mud-cap drilling has been employed in a limited manner in other oil producing regions of the world, Saudi Aramco is unique in the routine application of this methodology ${ }^{13}$.

Drilling with a floating mud-cap involves drilling ahead blind (i.e., without returns) by pumping different fluid densities down the drill string and annulus simultaneously ${ }^{13}$.

Procedures for mud cap drilling are shown in Figure (4.1).

\section{Mathematical model}

The following equations were used for killing calculations:

Formation pressure

$\mathrm{FP}=\mathrm{SIDPP}+0.052 \times \mathrm{OMW} \times \mathrm{TVD} \ldots . .(5-1)$ 
HYDROSTATIC PRESSURE

$(5-2)$

HP = MUD WEIGHT (PPG) X.052 X DEPTH (TVD) ......

KILL MUD WEIGHT MUD (PPG)

$\mathrm{KMW}=\mathrm{OMW}+(\mathrm{SIDPP} /(0.052 \times \mathrm{TVD})) \cdot(5-3)$

Initial circulating pressure

$I C P=S C R+S I D P P$

Final circulating pressure optimum

$\mathrm{FCP}=\mathrm{SCR} \times(\mathrm{KMW} / \mathrm{OMW})$

Maximum Allowable Mud Weight (ppg)

Step down $(\mathrm{PSI} / 100 \mathrm{STK})=\mathrm{PSI} / \mathrm{STK} \times 100$

\section{Data used}

1. Simulator case-1, case-2 and case-3(table 61,6-2, 6-3).

2. Actual well control field cases during drilling and workover operations table 6.4, 6.5, 6.6, $6.7,6.8,6.9,6.10)$.

\section{Work strategy}

1. Studying the factors that affecting killing operations using drilling simulator DRILL SIM 5000 by simulator cases.

2. Studying well control actual field cases during drilling and workover operations to study the learning lessons from each cases.

\section{Results}

In order to study the factors that affecting killing operations using simulator the factors (size of influx, type of influx, annular capacity and killing rate, gas influx behavior ) were changed then killing operations using simulator was performed and tried to read the chart for each factor (figure 8.1, 8.2, 8.3 ,8.4, $8.5,8,6,8.7,8.9)$.

Actual field cases was extracted from drilling report and studied to know the main cause of well control issue, the solution and the learning lessons to face these problems in the future.

\section{factors affecting killing operations}

1. Killing rate. From chart 8.1 and 8.2 As the killing rate increase as the friction pressure loss increase and cause increase system pressures but time og killing decrease so optimum killing rate should be detected

2. Type of influx fluid. Comparing between chart 8.1 and 8.3 gas influx at the same time of underbalance conditions exhibit more size of influx than water and oil influx due to gas mobility is higher than water and oil. Chart 8.4 shows gas migration effect on system pressure which increases continuously as gas migrate up.
3. Size of influx. Comparing between chart 8.1 and 8.5As the size of influx increase as the system pressure increase and kick handling will more difficult.

4. Annular capacity. Comparing between chart 8.5 and 8.6 As the annular capacity increase as the height of influx decrease and all system pressures

5. Killing method selections. From chart 8.7 due to gas migration effect bullheading method not effective for killing gas production wells especially with high rate of migrations. Comparing with chart 8.8 and 8.9 wait and wait method takes long time of calculations especially in deviated wells but with lower system pressures and lower killing operations time than driller method.

\section{learning lessons from actual field cases}

1. From case- 1 and case-2 Kick while cementing operations occurs due to spacer weight is not correct, losses occurs due to higher cement hydrostatic head and due to flush set for cement due to cement contamination with mud associated with cement channeling by gas.

2. From case-3 Blowout in FARAS field mainly occurred due to leak in diverter vent line.

3. From case-4Ballooning effect has similar behavior of kick while performing flow check, but the main difference the rate of flow from the well decreases with time.

4. From case-5 Gas kick detection is very difficult while drilling with oil base mud due to gas solubility in oil.

5. From case-6 Mud cap drilling is good solution to prevent kick while complete loss of circulation problem.

6. From case-7 communication between rig crew is very important while kick handling and lack of experience can cause the simplest situation too difficult.

7. From case-8 bad planning for killing operations causes loss time which effect on total well cost.

\section{Conclusions}

The conclusions that were drawn from this research:

1. Using conventional well head in gas wells lead to hang BOP after cementing intermediate casing. This means that the well should be left for long time without any barrier. Only cement would be as a barrier which could be channeled by gas.

2. Setting casing slips after cement setting did not provide slips(casing hanger) with enough weight to be set properly and to be considered as a 
mechanical barrier to isolate the gas cemented formations.

3. While cementing gas formation cement contamination with mud causes kick due to flush set of cement that isolate part of hydrostatic and cause kick.so if gases channeling occur kick could be blow out so it is essential to Add cement additives that prevent gas channeling to prevent gas kick.

4. Comparing gas kicks with water and oil kicks gas kicks are considered as the most dangerous kicks due to gas mobility which increases the size of influx at the same condition of underbalance, gas gravity differences which cause gas migration and increase system pressures and gas solubility in oil base mud which cause kick detection difficulties.

5. As formation permeability increase as the size of influx increase at the same conditions of underbalance.

6. Ballooning effect occurs in micro fractured formations due to high ECD but the big difference between ballooning effect and kick that while performing flow check the flow rate which coming from the well decreases with time not increases with time like the kick.

7. Mud cap drilling is good solution to drill sections which expected subsequent pipe sticking, complete loss of mud circulation and kick problem.

8. Top kill or staging in hole is good selection for off-bottom kick especially for small kick and short offbottom distance as it save time and cost rather than using stripping operations. But for more safe operation combination between top kill and stripping is recommended depend on owner company policy.

9. Bull heading is highly recommended when kick occurs while blind drilling (i.e.: drilling with complete loss of circulations).

10. For more safe and efficient gas production wells killing operations bullheading is not recommended due to the effect of gas migration especially in the wells of high of migration, so while designing well completion it is very important to keep way for communication between tubing and annulus and below and above the packer especially in gas wells for the next killing operation in the next workover works.

11. Reverse circulation method is highly recommended in workover wells due to highly formation fluid sweeping efficiency to surface and saving cost and time.

\section{Funding sources}

This research received no external funding.

\section{Conflicts of interest}

There are no conflicts to declare.
The acknowledgements come at the end of an article after the conclusions and before the and references.

\section{Notes and references}

[1] Well Control for the Rig-Site Drilling Team Training Manual, Aberdeen Drilling Schools and Well control t raining Centre, Aberdeen, Scotland, U.K., 2002.

[2] Well Control Training Manual, MAERSK Co. Training Centre and Drilling Section, 2002.

[3] Adams, N.: "Causes of Underground Blowouts," World Oil, January, 2006.

[4] Hornung M. R.:" Kick Prevention, Detection, and Control: Planning and Training Guidelines for Drilling Deep High-Pressure Gas Wells" Paper SPE 19990 presented at the IADC/SPE Drilling Conference, Houston, 1990.

[5] Saudi Aramco Drilling Manual Drilling Technical Department September 2013.

[6] Tawfik, Elshehabi: "An Integrated Model for Gas Kick Control during Drilling Deviated Wells" M.Sc. Thesis, Suez University, 2008.

[7] Work over Well Control and Blowout Prevention Guide Volume 15 Copyright, 1994 Chevron Petroleum Technology Company.

[8] Grottheeim, O.E.: "Development and Assessment of Electronic Manual for Well Control and Blowout Containment," M.Sc. Thesis, Texas A\&M University, College Station, Texas, 2005

[9] Adams, N. and Young, R.: "Underground Blowouts: What You Need To Know," World Oil (January 2004).

[10] Watson, D., Brittenham, T., and Moore, P.L.: Advanced Well Control, Text Book Series, SPE, Richardson, Texas (2003).

[11] Schubert, J.J.: "Well Control Procedures for the Proper Identification and Handling of Kicks for the Prevention of Blowouts," MEng Report, Texas A\&M University, College Station, Texas, 1995.

\section{Acknowledgements}


[12] Volumetric methods and stripping operations, Muscat, Oman Training Center August, 2007.

[13] Armco Well Control Manual 5th Edition Volume II, 2013.

\section{Nomenclature}
FP = formation pressure, $p s i$
$\mathrm{HP}=$ hydrostatic pressure, $\mathrm{psi}$.
SIDPP $=$ Shut in drill pipe pressure, $\mathrm{psi}$
SICP = Shut in casing pressure, $\mathrm{psi}$
TVD $=$ Total vertical depth, $\mathrm{ft}$.
$\mathrm{MD}=$ Measured depth, $\mathrm{ft}$.
OMW = Old or original mud weight, ppg.
$\mathrm{KMW}=$ Kill mud weight, ppg.
SPM = Stroke per minute.
ICP = Initial circulating pressure, psi.
SCR = Slow Circulating Rate Pressure, psi.
$\mathrm{FCP}=$ Final circulating pressure, psi. 


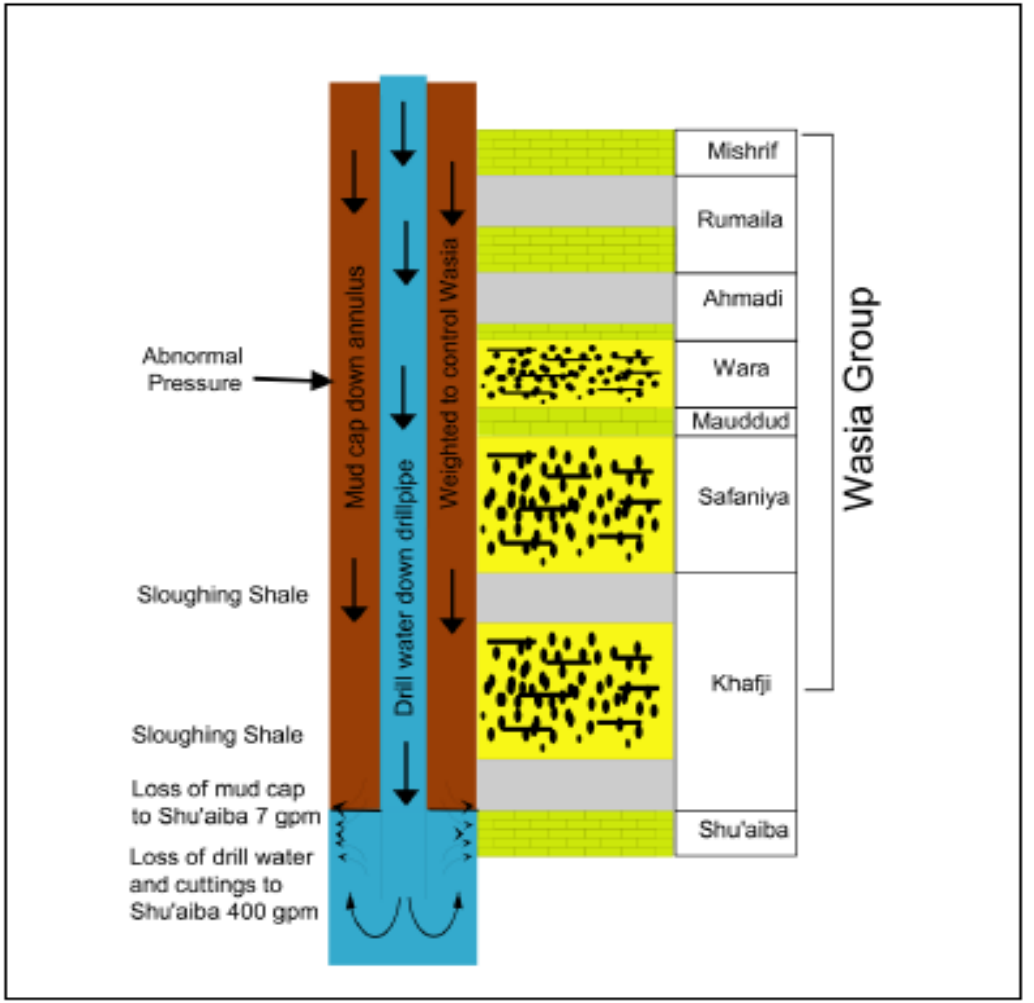

Figure 4.5 - Mud cap drilling 5 .

Pressure and SPM

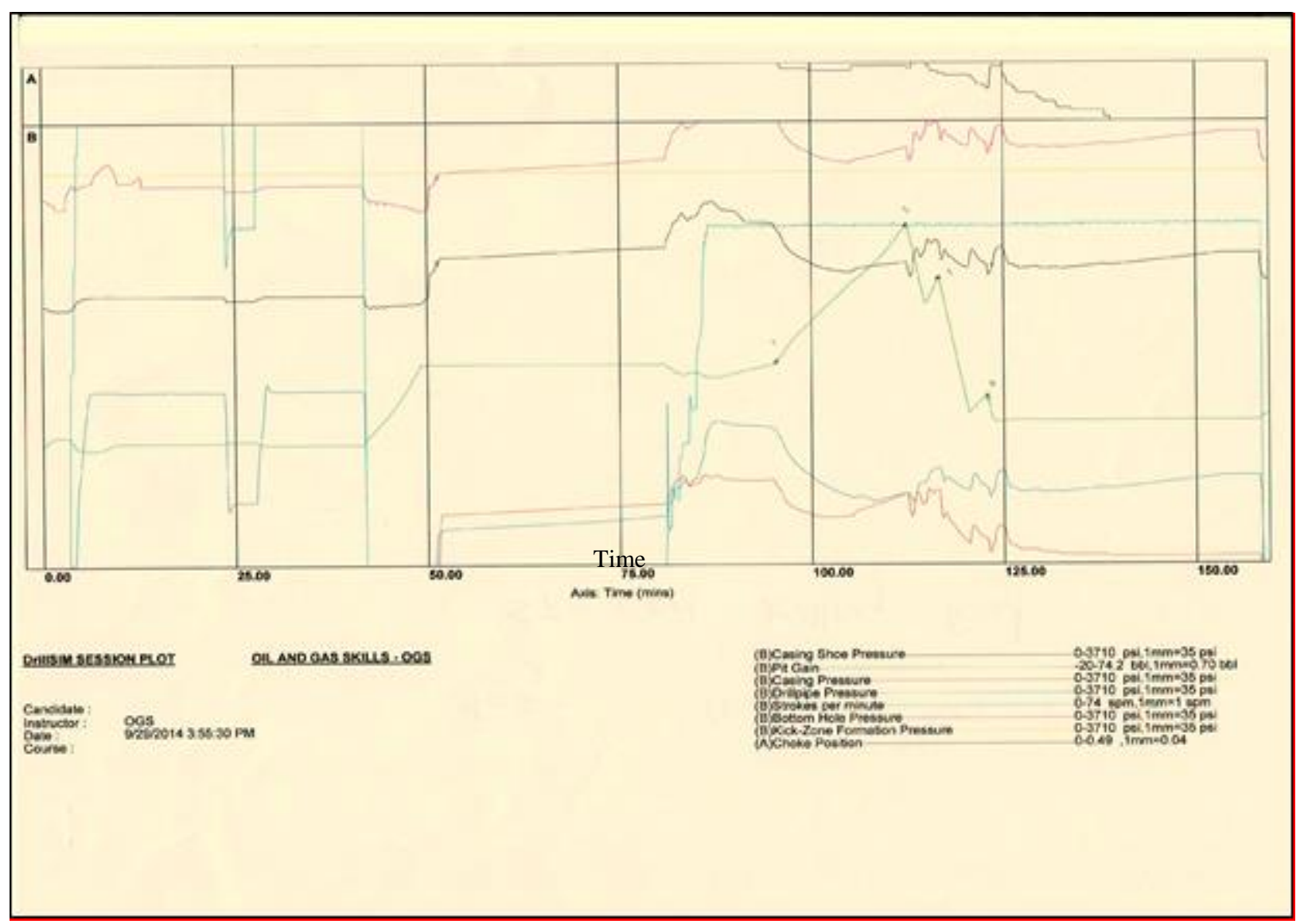

Figure 8.1- killing procedures of 16 BBLS gas kick, with 60 SPM killing rate using simulator case-1 
Figure 8.2 killing procedures of 16 BBLS gas kick, with 30 SPM killing rate using simulator case-1

Pressure and SPM

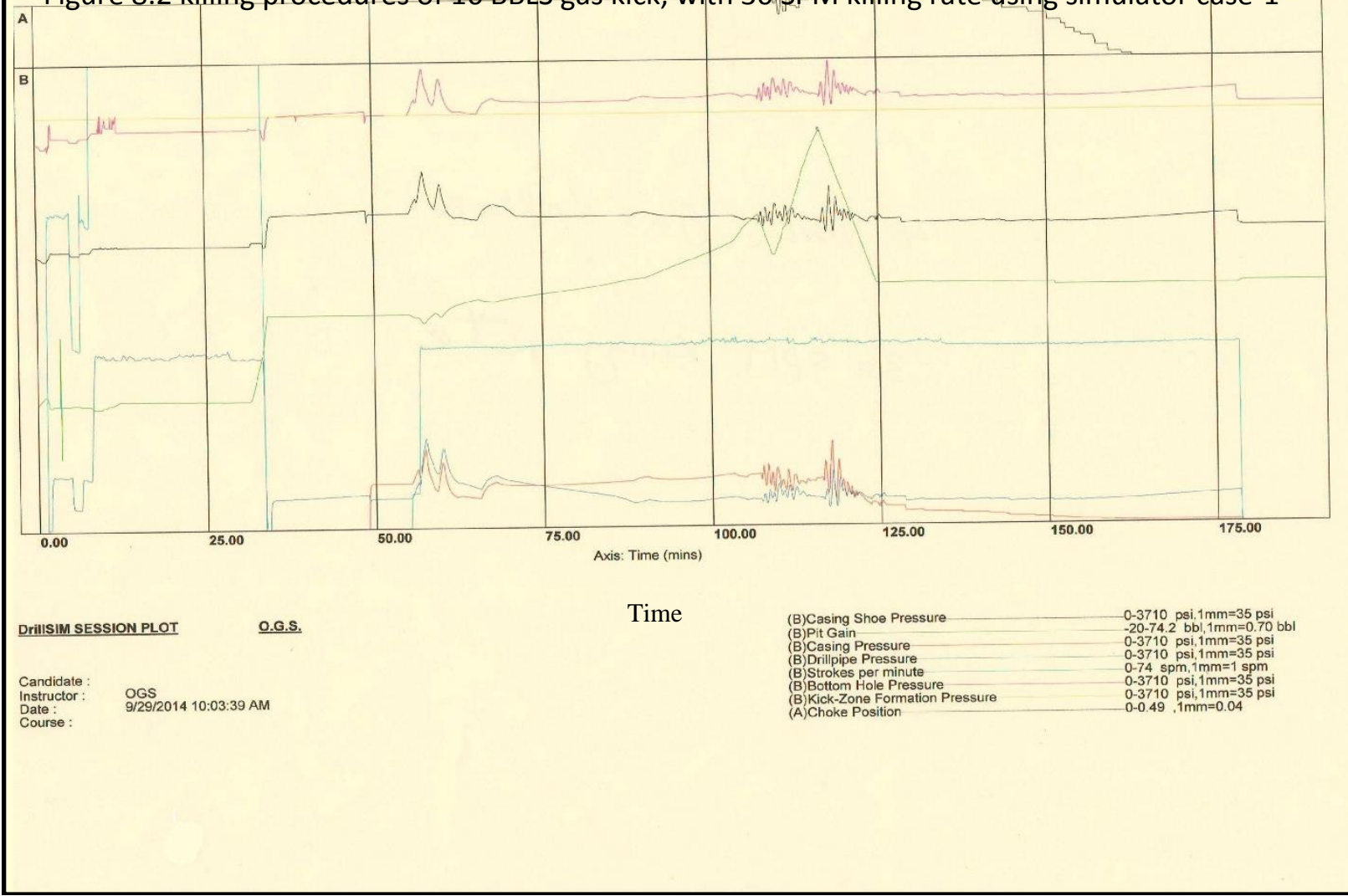

Pressure and SPM

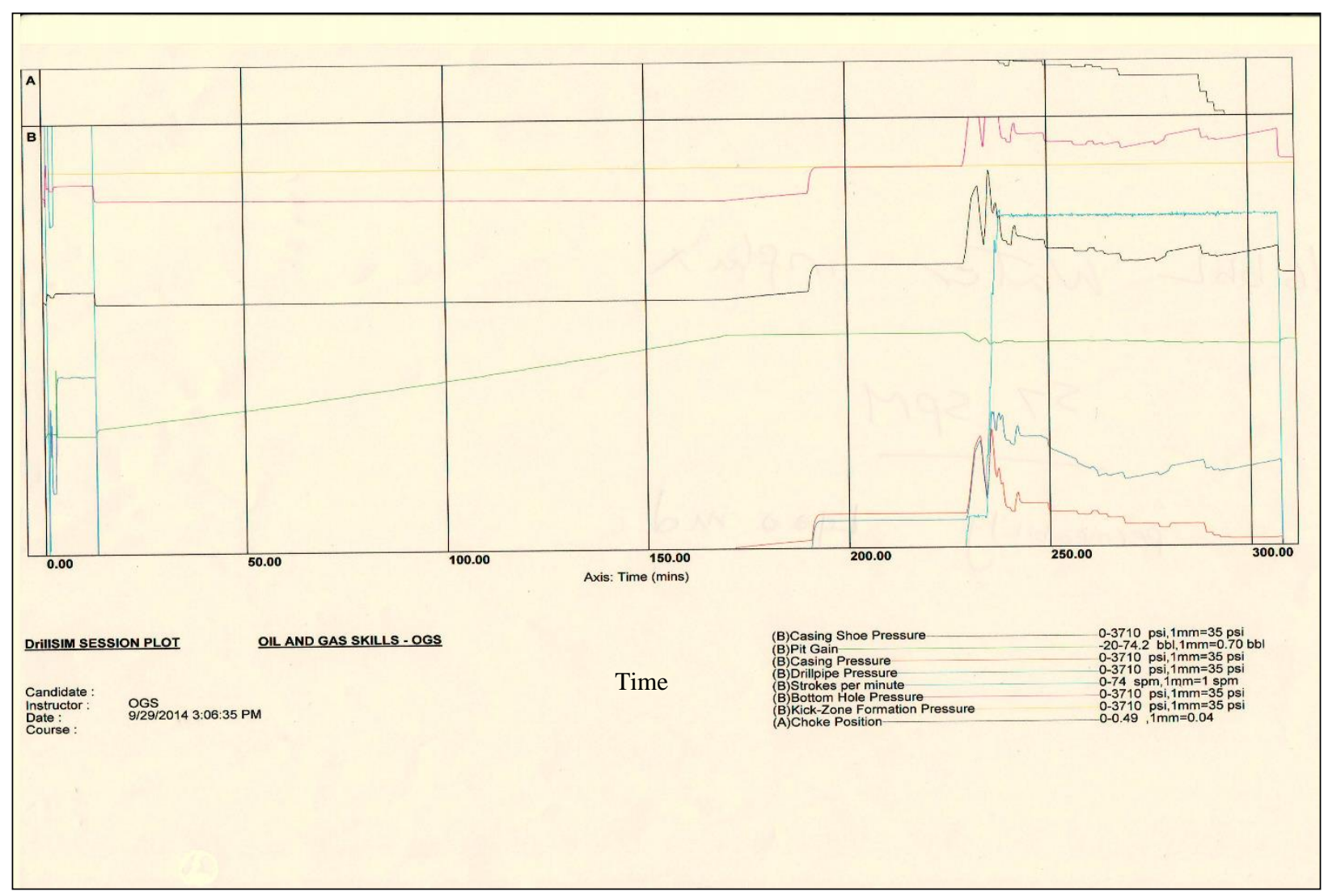

Figure 8.3-killing procedures of 16 BBLS water kick, with 60 SPM killing rate 


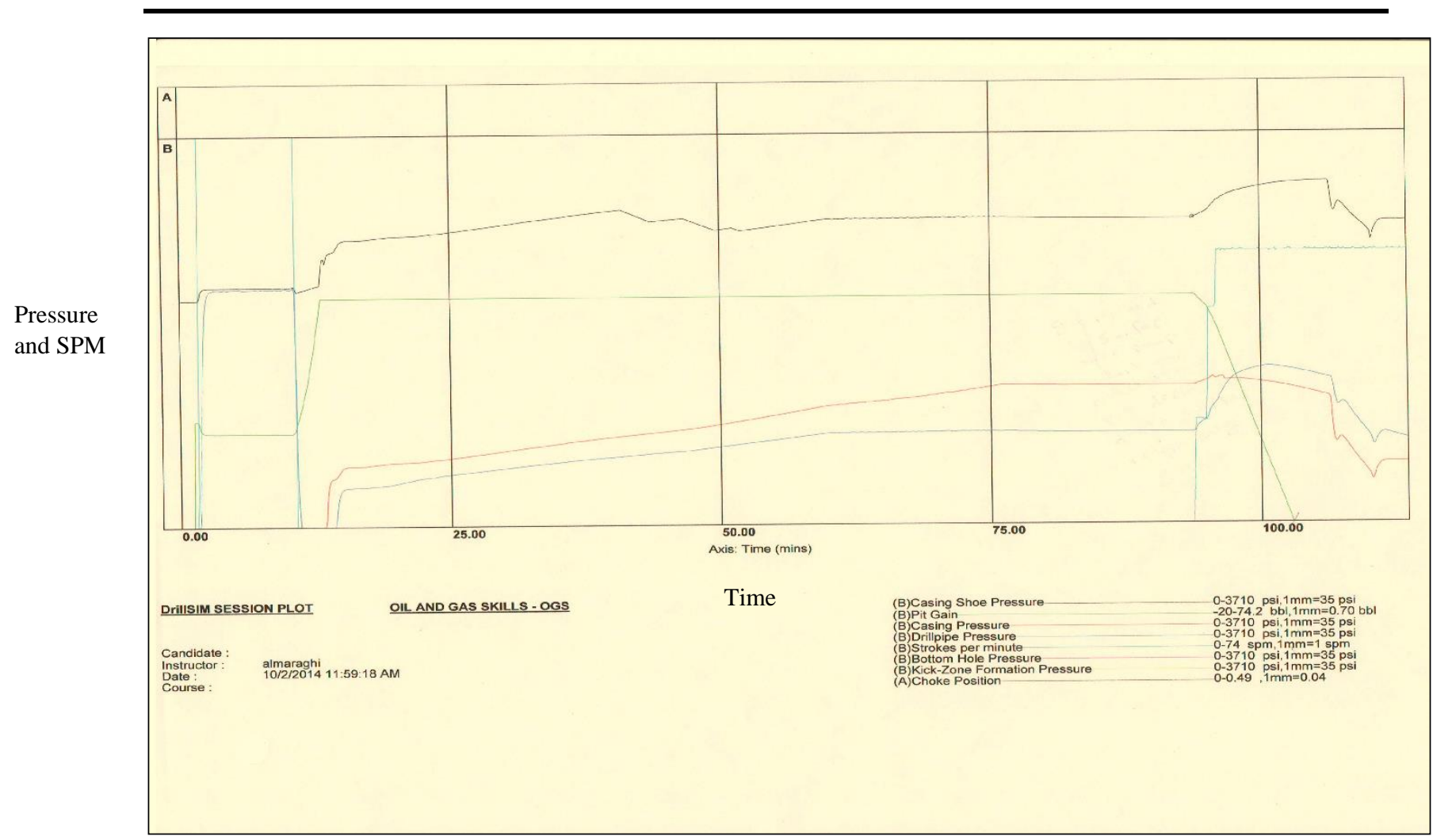

Figure 8.4 16 BBLS gas kick, effect of gas migration using simulator case-1

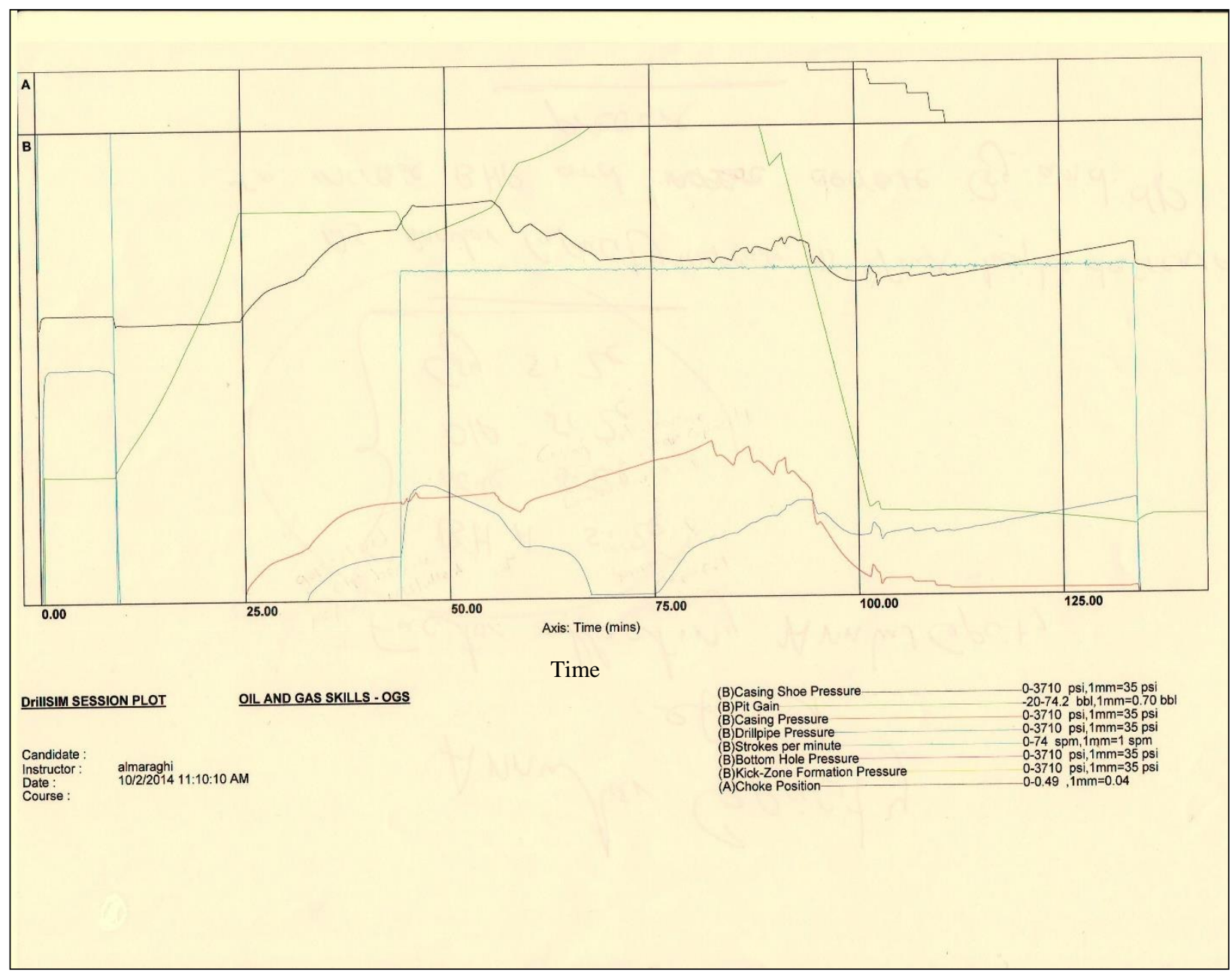

Figure 8.5 killing procedures of 64 BBLS gas kick, with 60 SPM killing rate 


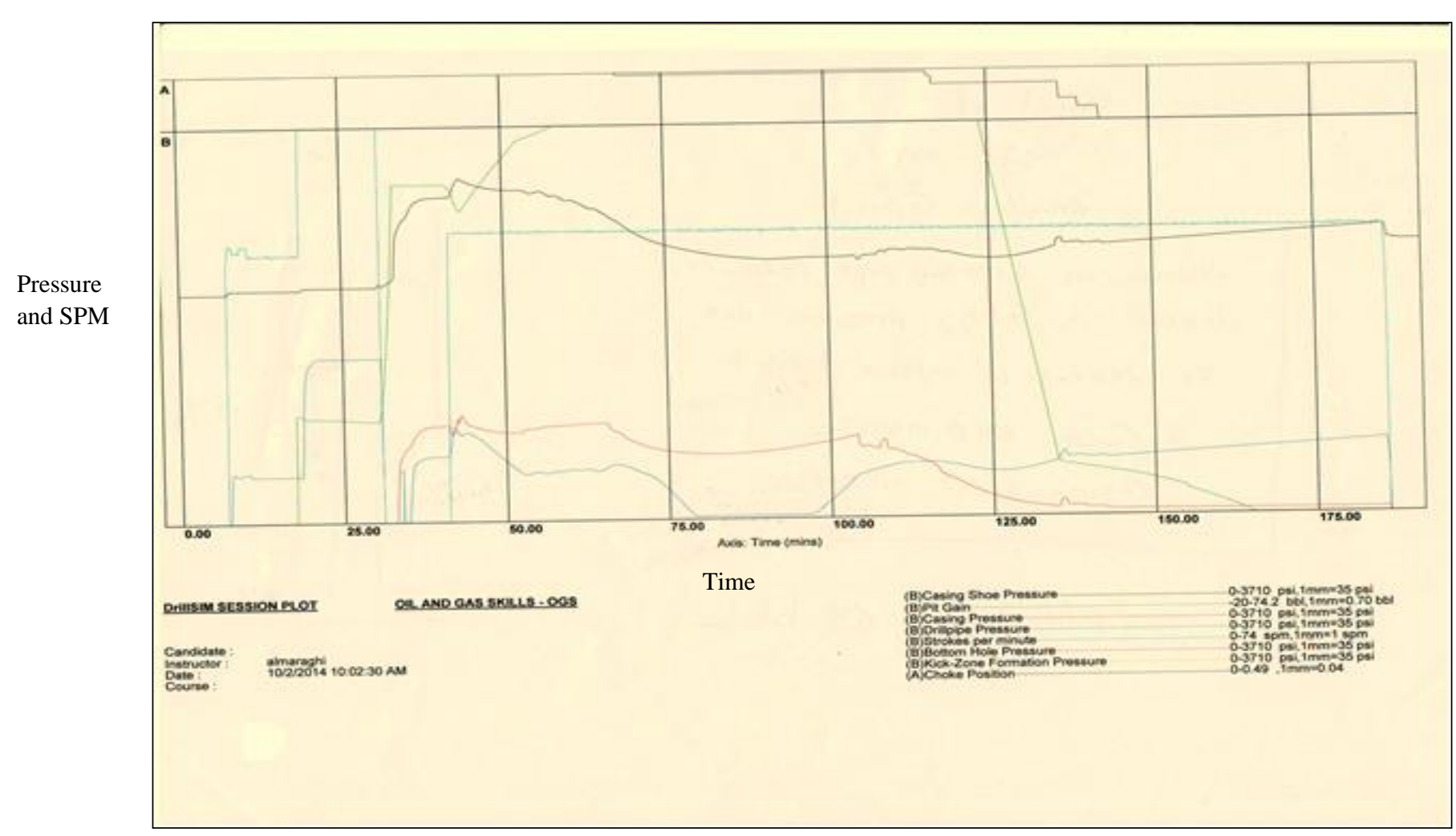

Figure 8.6 Annular capacity effect.

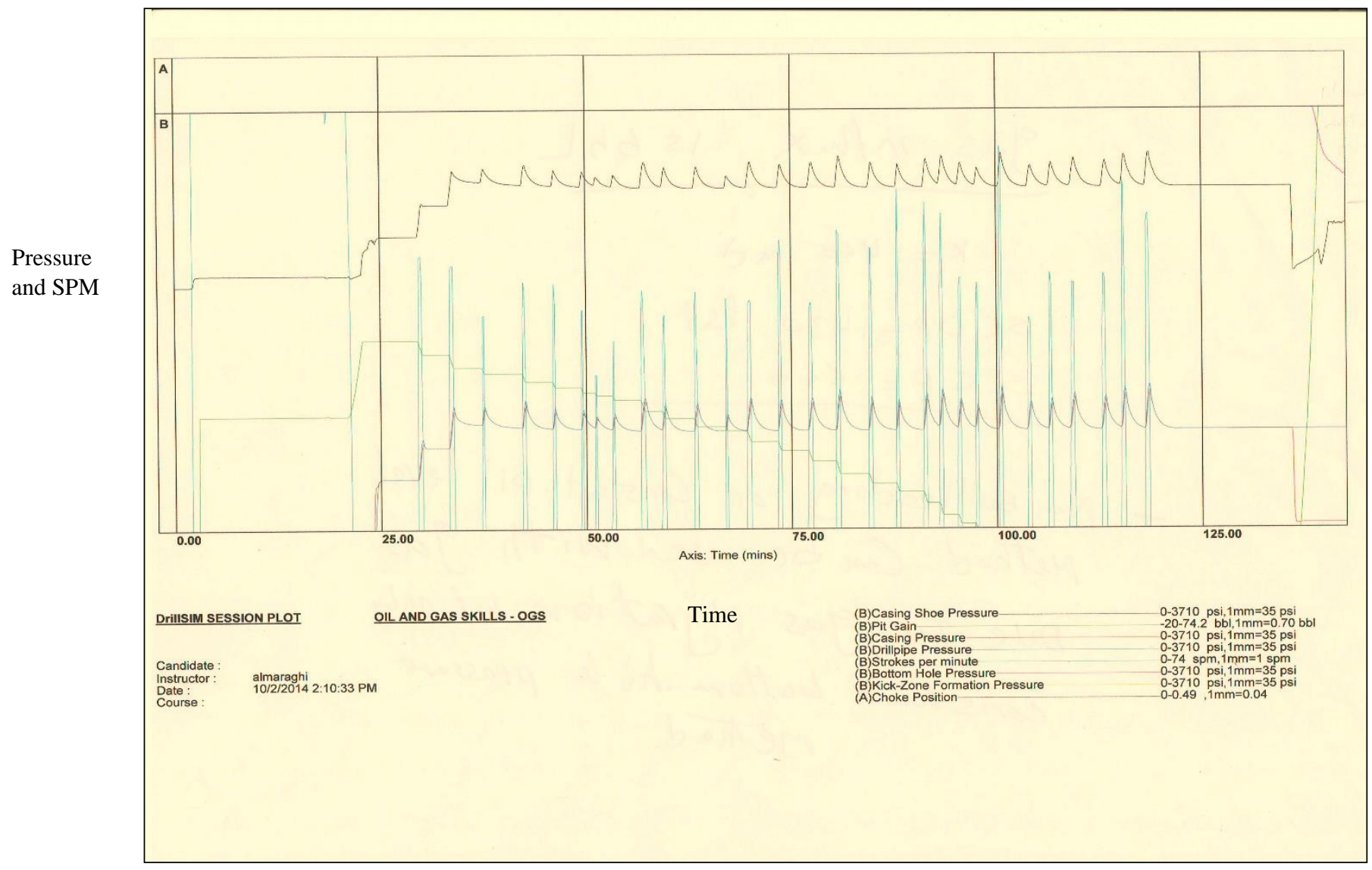

Figure 8.7 bullhead 15 BBLS gas kick permeability (k)400 MD 


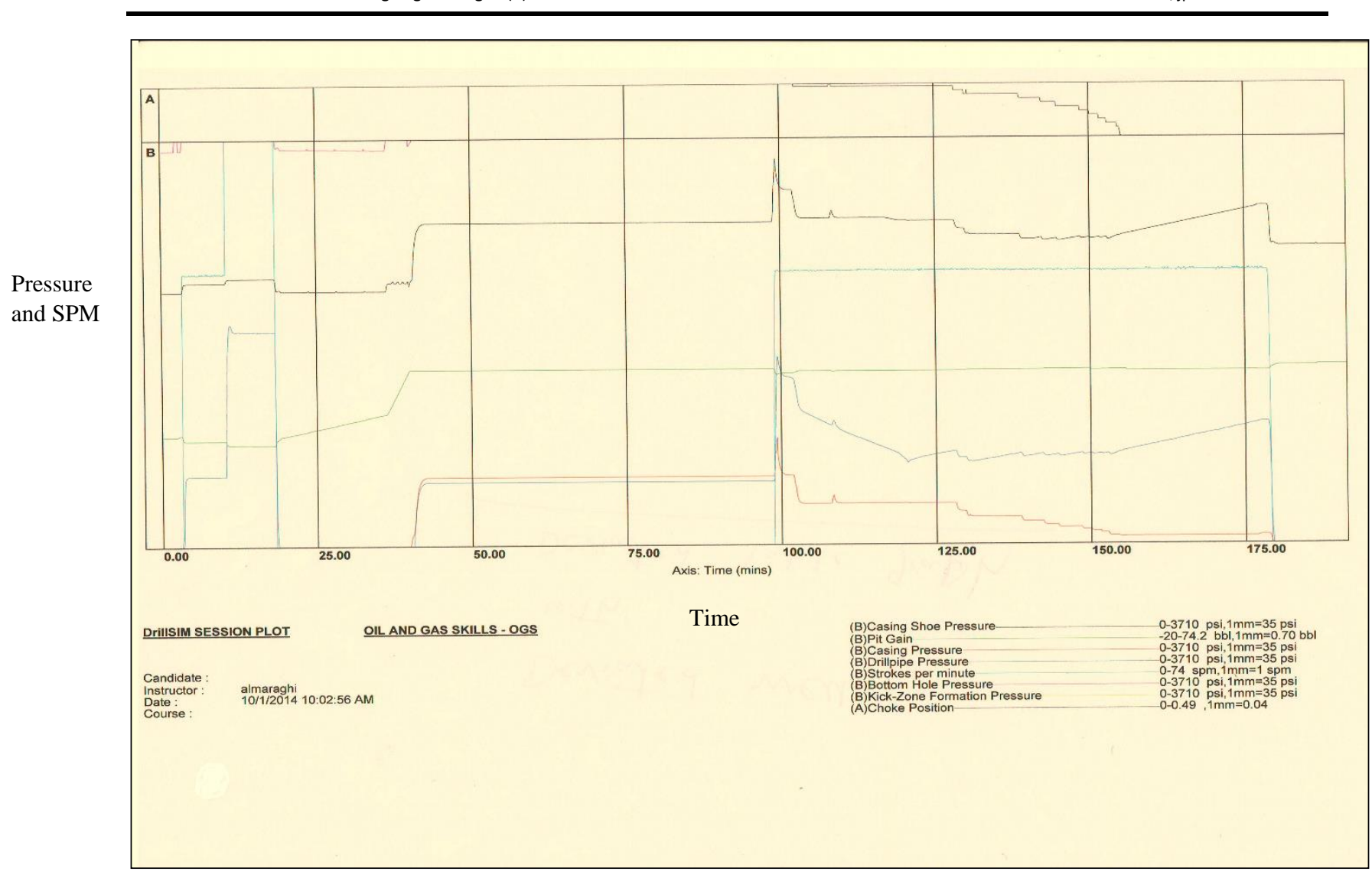

Figure 8.8-25 BBLS water kick, 60 SPM killing rate wait and weight method using case-3

Pressure and SPM

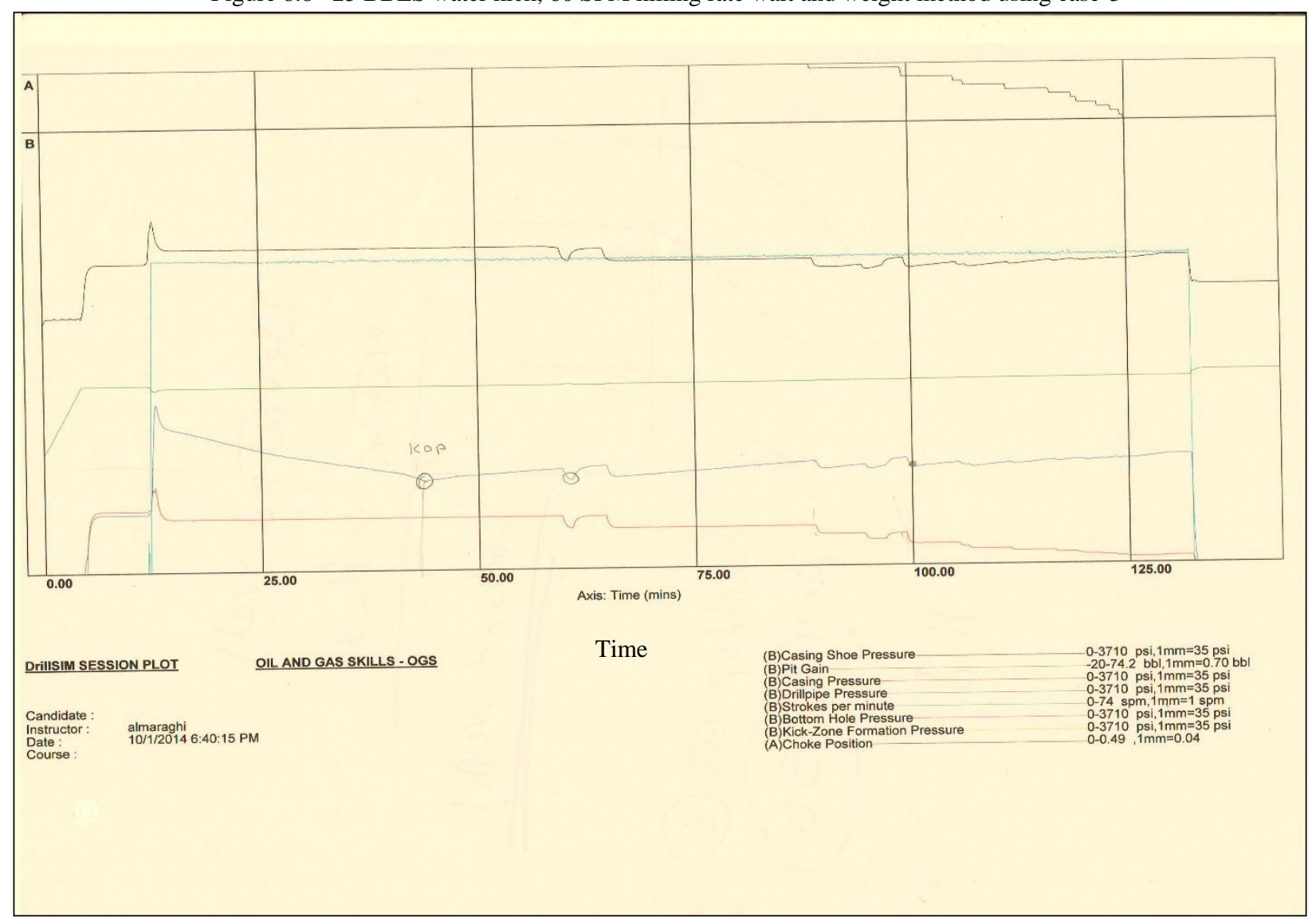

Figure 8.9 - 25 BBLS water kick, 60 SPM killing rate killing with driller method

Table 6.1- simulator Case-1

Table 6.2- simulator Case-1

Simulator Case-1 


\begin{tabular}{|c|c|c|c|c|c|}
\hline \multicolumn{3}{|l|}{ Hole data } & & & \\
\hline Hole size & $81 / 2$ & in & \multicolumn{3}{|l|}{ Simulator Case-2 } \\
\hline Hole depth MD & 5580 & $\mathrm{ft}$ & \multicolumn{3}{|l|}{ Hole data } \\
\hline Hole depth TD & 5580 & $\mathrm{ft}$ & Hole size & $81 / 2$ & in \\
\hline Casing depth MD (9 5/8") & 3950 & $\mathrm{ft}$ & Hole depth MD & 7500 & $\mathrm{ft}$ \\
\hline Casing depth TD (9 5/8") & 3950 & $\mathrm{ft}$ & Hole depth TD & 7500 & $\mathrm{ft}$ \\
\hline \multicolumn{3}{|l|}{ Drill string data } & Casing depth MD (13.375") & 3950 & $\mathrm{ft}$ \\
\hline Drill pipe 5 " capacity & 0.0174 & $\mathrm{bbl} / \mathrm{ft}$ & Casing depth TD (13.375") & 3950 & $\mathrm{ft}$ \\
\hline Heavy wall pipe 5 " length & 810 & $\mathrm{ft}$ & \multicolumn{3}{|l|}{ Drill string data } \\
\hline Heavy wall pipe capacity & 0.0087 & $\mathrm{bbl} / \mathrm{ft}$ & Drill pipe 5 " capacity & 0.0174 & $\mathrm{bbl} / \mathrm{ft}$ \\
\hline Drill collar length & 600 & $\mathrm{ft}$ & Heavy wall pipe 5 " length & 900 & $\mathrm{ft}$ \\
\hline Drill collar capacity & 0.0061 & $\mathrm{bbl} / \mathrm{ft}$ & Heavy wall pipe capacity & 0.0087 & $\mathrm{bbl} / \mathrm{ft}$ \\
\hline Capacity open hole $\mathrm{x}$ drill collar & 0.029 & $\mathrm{bbl} / \mathrm{ft}$ & Drill collar length & 750 & $\mathrm{ft}$ \\
\hline Capacity open hole $\mathrm{x}$ drill pipe & 0.0459 & $\mathrm{bbl} / \mathrm{ft}$ & Drill collar capacity & 0.0061 & $\mathrm{bbl} / \mathrm{ft}$ \\
\hline Capacity casing $\mathrm{x}$ drill pipe & 0.3759 & $\mathrm{bbl} / \mathrm{ft}$ & Capacity open hole $\mathrm{x}$ drill collar & 0.029 & $\mathrm{bbl} / \mathrm{ft}$ \\
\hline \multicolumn{3}{|l|}{ Kick data } & Capacity open hole $\mathrm{x}$ drill pipe & 0.0459 & $\mathrm{bbl} / \mathrm{ft}$ \\
\hline Pit gain & 16 gas & bbl & Capacity casing $\mathrm{x}$ drill pipe & 0.3759 & $\mathrm{bbl} / \mathrm{ft}$ \\
\hline SIDPP & 310 & psi & \multicolumn{3}{|l|}{ Kick data } \\
\hline SICP & 440 & psi & Pit gain & 60 gas & bbl \\
\hline \multicolumn{3}{|l|}{ Mud data } & SIDPP & 640 & psi \\
\hline Drilling fluid density & 10.5 & ppg & SICP & 895 & psi \\
\hline \multicolumn{3}{|l|}{ Other data } & \multicolumn{3}{|l|}{ Mud data } \\
\hline \multirow{2}{*}{$\begin{array}{l}\text { Fracture fluid density at casing } \\
\text { shoe }\end{array}$} & \multirow[t]{2}{*}{17.9} & \multirow{2}{*}{ ppg } & Drilling fluid density & 10.5 & ppg \\
\hline & & & \multicolumn{3}{|l|}{ Other data } \\
\hline \multirow{2}{*}{$\begin{array}{l}\text { Slow circulating pressure at } 60 \\
\text { SPM }\end{array}$} & \multirow[t]{2}{*}{530} & \multirow[t]{2}{*}{ psi } & Fracture fluid density at casing shoe & 17.5 & ppg \\
\hline & & & Slow circulating pressure at $60 \mathrm{SPM}$ & 430 & psi \\
\hline Mud pump displacement & 0.099 & \multirow[t]{2}{*}{$\begin{array}{l}\mathrm{bbl} / \mathrm{stro} \\
\mathrm{ke}\end{array}$} & Mud pump displacement & 0.099 & bbl/str \\
\hline \multicolumn{2}{|l|}{ Calculated data } & & \multirow{2}{*}{\multicolumn{3}{|c|}{ Calculated data }} \\
\hline \multirow[t]{2}{*}{ Strokes to bit } & \multirow{2}{*}{830} & \multirow[t]{2}{*}{ strokes } & & & \\
\hline & & & Strokes to bit & 1190 & strokes \\
\hline Strokes from bit to surface & 2520 & strokes & Strokes from bit to surface & 5103 & strokes \\
\hline Strokes from bit to shoe & 645 & strokes & Strokes from bit to shoe & 1538 & strokes \\
\hline Kill mud density & 11.6 & ppg & & & \\
\hline Initial circulating pressure ICP & 840 & $n \mathrm{si}$ & Kill mud density & 12.5 & ppg \\
\hline & & & Initial circulating pressure ICP & 1070 & psi \\
\hline Final circulating pressure FCP & 585 & psi & Final circulating pressure FCP & 512 & psi \\
\hline Step down & 30 & $\begin{array}{l}\mathrm{psi} / 100 \\
\text { strokes }\end{array}$ & Step down & 46 & $\begin{array}{l}\mathrm{psi} / 100 \\
\text { strokes }\end{array}$ \\
\hline
\end{tabular}

\begin{tabular}{|l|l|l|}
\hline \multicolumn{3}{|c|}{ Simulator Case-3 } \\
\hline \multicolumn{3}{|c|}{ Hole data } \\
\hline Hole size & $81 / 2$ & in \\
\hline Hole depth MD & 9730 & $\mathrm{ft}$ \\
\hline \hline
\end{tabular}




\begin{tabular}{|c|c|c|}
\hline Hole depth TD & 7507 & $\mathrm{ft}$ \\
\hline Kick of point MD/TVD (KOP) & 2000 & $\mathrm{ft}$ \\
\hline Build rate & 2 & Deg/100ft \\
\hline Final inclination & 50 & deg \\
\hline End of build (EOB) TVD & 5050 & $\mathrm{ft}$ \\
\hline End of build (EOB) MD & 4500 & $\mathrm{ft}$ \\
\hline Casing depth MD (9 5/8") & 3950 & $\mathrm{ft}$ \\
\hline Casing depth TD (9 5/8") & 3950 & $\mathrm{ft}$ \\
\hline \multicolumn{3}{|c|}{ Drill string data } \\
\hline Drill pipe 5 " capacity & 0.0174 & $\mathrm{bbl} / \mathrm{ft}$ \\
\hline Heavy wall pipe 5 " length & 900 & $\mathrm{ft}$ \\
\hline Heavy wall pipe capacity & 0.0087 & $\mathrm{bbl} / \mathrm{ft}$ \\
\hline Drill collar length & 750 & $\mathrm{ft}$ \\
\hline Drill collar capacity & 0.0061 & $\mathrm{bbl} / \mathrm{ft}$ \\
\hline $\begin{array}{l}\text { Capacity open hole x drill } \\
\text { collar }\end{array}$ & 0.029 & $\mathrm{bbl} / \mathrm{ft}$ \\
\hline Capacity open hole $\mathrm{x}$ drill pipe & 0.0459 & $\mathrm{bbl} / \mathrm{ft}$ \\
\hline Capacity casing $\mathrm{x}$ drill pipe & 0.3759 & $\mathrm{bbl} / \mathrm{ft}$ \\
\hline \multicolumn{3}{|c|}{ Kick data } \\
\hline Pit gain & $\begin{array}{l}25 \\
\text { water }\end{array}$ & bbl \\
\hline SIDPP & 480 & psi \\
\hline SICP & 517 & psi \\
\hline \multicolumn{3}{|l|}{ Mud data } \\
\hline Drilling fluid density & 10.5 & ppg \\
\hline \multicolumn{3}{|l|}{ Other data } \\
\hline $\begin{array}{l}\text { Fracture fluid density at casing } \\
\text { shoe }\end{array}$ & 17.9 & ppg \\
\hline $\begin{array}{l}\text { Slow circulating pressure at } 60 \\
\text { SPM }\end{array}$ & 660 & psi \\
\hline Mud pump displacement & 0.1028 & bbl/stroke \\
\hline
\end{tabular}

Table 6.3 Simulator Case-3

\begin{tabular}{|l|c|l|}
\hline \multicolumn{3}{|c|}{ Cimulator Case-3 } \\
\hline Calculated \\
\hline Strokes to bit & 1517 & strokes \\
\hline Strokes from bit to surface & 4460 & strokes \\
\hline D.P -surface to KOP strokes & 346 & strokes \\
\hline D.P -KOP to EOB strokes & 273 & strokes \\
\hline D.P -EOB to BHA strokes & 778 & strokes \\
\hline HWDP stroke & 76 & strokes \\
\hline D.C stroke & 44 & strokes \\
\hline Strokes from bit to shoe & 2480 & strokes \\
\hline Kill mud density & 11.8 & ppg \\
\hline Initial circulating pressure ICP & 1140 & psi \\
\hline Final circulating pressure FCP & 742 & psi \\
\hline Step down 1 & 34 & $\begin{array}{l}\text { psi/100 } \\
\text { stroke }\end{array}$ \\
\hline Step down 2 & 29 & $\begin{array}{l}\text { psi/100 } \\
\text { strokes }\end{array}$ \\
\hline Step down 2 & 22 & $\begin{array}{l}\text { psi/100 } \\
\text { strokes }\end{array}$ \\
\hline
\end{tabular}

Table 6.4- Actual Field Case-1and Case-2 (Kick While Cementing Operations) 


\begin{tabular}{|c|c|c|}
\hline Case number & Case 1 & Case 2 \\
\hline Well Field & $\begin{array}{ll} & \text { Western desert Egypt Faras field }\end{array}$ & $\begin{array}{ll}- & \text { Saudi Arabia El Ghwar field }\end{array}$ \\
\hline $\begin{array}{l}\text { Open Hole Geological } \\
\text { Date }\end{array}$ & $\begin{array}{ll}\text { - } & \text { Apollonian FM mainly limestone } \\
\text { containing limited gas quantity with initial } \\
\text { abnormal pressure, } \\
\text { - } & \text { Khoman,A/R,F\&G FM } \\
\text { - } & \text { Shale and limestone without expected well } \\
\text { control problem. } \\
\text { - } \quad \text { Baharya FM:- } \\
\text { - } \quad \text { Pay zone ,mainly sand silt shale. }\end{array}$ & 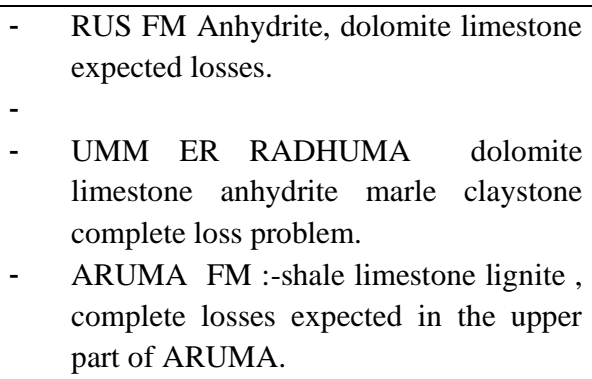 \\
\hline Well Data & $\begin{array}{ll}- & \text { Hole size } 8.5^{\prime \prime} \\
- & \text { Hole depth } 3400 \mathrm{ft} \\
- & 9-5 / 8 " \text { Csg shoe } 1500 \mathrm{ft} \\
\end{array}$ & $\begin{array}{ll}- & \text { Hole size } 24 " \\
- & \text { Hole depth } 945 \mathrm{ft} \\
- & 30 " \text { Csg shoe } 155 \mathrm{ft} \\
\end{array}$ \\
\hline Mud Data & $\begin{array}{l}\text { - } \quad \text { Salt saturated mud with barite mud } 11.5 \\
\text { ppg }\end{array}$ & Polymer mud with barite mud $14.2 \mathrm{ppg}$ \\
\hline Operation Before Kick & $\begin{array}{ll}\text { - } & \text { Run in hole with 7" casing to } 3400 \mathrm{ft} . \\
\text { - } & \text { Starting cement job }\end{array}$ & $\begin{array}{l}\text { - Finished cement job, attempted to pick } \\
\text { casing to remove slips but failed, wait on } \\
\text { cement, started lifting the diverter and } \\
\text { cutting 24"casing. }\end{array}$ \\
\hline Well Control Event & $\begin{array}{l}\text { - pumped chemical wash ,mud push and } \\
\text { cement slurry then started displacing } \\
\text { cement slurry after displacing } 86 \text { bbls } \\
\text { well started flowing }\end{array}$ & $\begin{array}{l}\text { - While cutting 24" casing and well } \\
\text { without any barrier as the diverter lifted } \\
\text { up to finalize casing cutting job the well } \\
\text { started flowing }\end{array}$ \\
\hline Action taken & $\begin{array}{l}\text { - Closing the well with soft shut-in } \\
\text { procedures. } \\
\text { Continued cement displacing through } \\
\text { choke, keeping } 500 \text { psi over balance the } \\
\text { formation pressure using choke, till } \\
\text { finished, closed the well, while keeping } \\
500 \text { psi, woc. } \\
\text { Check for gases using portable gas } \\
\text { detector. }\end{array}$ & $\begin{array}{l}\text { Directly reinstalled, activated the } \\
\text { diverter, and started diverting flow to } \\
\text { waste pit, flow was water and nitrogen } \\
\text { then after } 3 \text { days of diverting h2s started } \\
\text { to appear, leak occurred on vent line, fix } \\
\text { the leak and then continued diverting the } \\
\text { flow to waste pit then decided to bullhead } \\
\text { the well with kill mud loaded with LCM } \\
\text { material to cure losses then performed } \\
\text { cement job adding gas block additives. }\end{array}$ \\
\hline Observation & $\begin{array}{l}\text { - } \quad \text { Bad action by pumping chemical wash } \\
\text { with mud weight } 8.33 \text { ppg. } \\
\text { - Good action by adding gas block to } \\
\text { prevent gas migration }\end{array}$ & 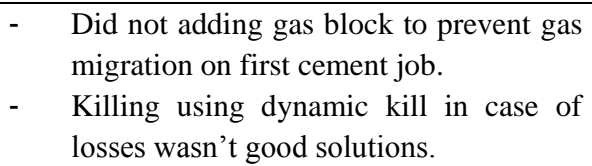 \\
\hline
\end{tabular}

Table 6.5- Actual Field Case-3 (Blow out due to Shallow Gas)

\begin{tabular}{|l|ll|}
\hline Case number & & \multicolumn{1}{c|}{ Case-3 } \\
\hline Well Field & - & Faras field Egyptian western desert. \\
\hline $\begin{array}{l}\text { Open Hole Geological } \\
\text { Date }\end{array}$ & - & Moghra FM it mainly claystone and sand. \\
\hline Well Data & - & Hole size 17.5" \\
& - & Hole depth 511 ft \\
& - & Last casing shoe @ conductor pipe 20" @ $120 \mathrm{ft}$. \\
\hline Mud Data & - & 10 ppg salt saturated mud, using barite to increase mud weight to $10 \mathrm{ppg}$. \\
\hline
\end{tabular}




\begin{tabular}{|l|ll|}
\hline Operation Before Kick & - & Finished drilling 17.5"hole without any problem \\
& - & Circulated and swept hole with high viscous mud for hole cleaning, preparing for wiper trip. \\
\hline Well Control Event & - & Pulled out of hole two stand of 17.5" drilling assembly when well started flowing. \\
\hline Action taken & - & $\begin{array}{l}\text { Directly activated the diverter and started flow diverting far away from the rig. } \\
\text { Observation }\end{array}$ \\
& - & Suddenly the fire started on sub-base and cellar area. \\
& - & $\begin{array}{l}\text { Although shallow gas was expected in this area but pilot hole drilling wasn't recommended in } \\
\text { Second diverter line wasn't installed. }\end{array}$ \\
\hline
\end{tabular}

Table 6.6- Actual Field Case-4(Ballooning Effect)

\begin{tabular}{|c|c|}
\hline Case number & Case 4 \\
\hline Well Field & Egyptian Western Desert. \\
\hline $\begin{array}{l}\text { Open Hole Geological } \\
\text { Date }\end{array}$ & $\begin{array}{ll}\text { - } & \text { Apollonian FM :- } \\
\text { - } & \text { mainly limestone containing limited gas quantity with initial abnormal pressure, } \\
\text { - } & \text { Khoman,A/R,F\&G FM:- } \\
\text { - } & \text { Shale and limestone without expected well control problem. } \\
\text { - } & \text { Baharya FM:- } \\
\text { - } & \text { Pay zone ,mainly sand silt shale }\end{array}$ \\
\hline Well Data & $\begin{array}{ll}- & \text { Hole size 8.5" } \\
\text { - } & \text { Hole depth 6500ft } \\
\text { - } & \text { Last casing 9-5/8" shoe @3685 }\end{array}$ \\
\hline Mud Data & - $\quad$ Salt polymer mud , 9.4 ppg \\
\hline Operation Before Kick & - $\quad$ Operation was drilling 8.5" hole when observed down hole losses +/- $30 \mathrm{BPH}$ \\
\hline Well Control Event & - $\quad$ Stopped pump to check static losses found well flowing \\
\hline Action taken & - $\quad$ Directly shut-in the well using soft shut-in procedures, found SIDP=SICP=0 \\
\hline Observation & $\begin{array}{l}\text { - } \quad \text { Losses start as pump on and stooped when pump off. } \\
\text { - } \quad \text { this occurred when mud weight increased to } 9.4 \mathrm{ppg} \text { to achieve well bore stability against } \\
\text { active pressurized shale in A/G FM } \\
\text { - } \quad \text { Apollonian is fracture limestone. } \\
\text { - } \quad \text { Fast shut-in the well is good action from driller. }\end{array}$ \\
\hline
\end{tabular}


Table 6.7 Actual Field Case-5 Gas Influx Behavior with OBM

\begin{tabular}{|c|c|}
\hline Case number & Case-5 \\
\hline Well field & - $\quad$ Suez Gulf, off shore well. \\
\hline $\begin{array}{l}\text { Open Hole Geological } \\
\text { Date }\end{array}$ & - $\quad$ SUDR FM limestone contains gas. \\
\hline Well Data & $\begin{array}{ll}- & \text { Hole size 6" } \\
\text { - } & \text { Hole depth } 13051 \mathrm{ft} \mathrm{MD} \\
\text { - } & \text { Last casing 7" casing shoe @ } 7400 \mathrm{ft} \mathrm{MD}\end{array}$ \\
\hline Mud Data & - $\quad 9.5$ ppg oil base mud. \\
\hline Operation Before Kick & - $\quad$ Decided to pull out of hole for short trip to check for hole condition. \\
\hline Well Control Event & $\begin{array}{l}\text { - After started Pulling out of hole to } 12780 \mathrm{ft} \text {, problem occurred on top drive system stopped } \\
\text { tripping out of hole and started to fix the TDS problem. } \\
\text { At 07:00 hours the pit volume had increased to } 387 \mathrm{bbls} \text {. the gas started increasing at around } \\
\text { 12991 ft, at 08:30 hrs. At 09:00 hrs the volume was at } 400 \text { bbls and the gas up to } 2 \% \text {. } \\
\text { The pit volume remained constant till 10:00 hrs. It then continued to increase to } 405 \mathrm{bbls} \text { at } \\
\text { which time the gas had increased to } 9 \% \text {. The gas reached a maximum of } 14.5 \% \text { and a } \\
\text { maximum pit volume of } 407 \text { bbls. The total pit gain was approximately } 20 \text { bbls and occurred } \\
\text { from 08:30 till the well was shut in. }\end{array}$ \\
\hline Action taken & $\begin{array}{l}\text { - } \quad \text { Shut in on the hydril and the pressures on the drill-pipe and casing stabilized at SIDPP }=850 \\
\text { psi and SICP of } 890 \mathrm{psi} \text {, Increased mud weight to } 11.3 \mathrm{ppg} \text { and kill the well using Wait and } \\
\text { Weight Method. }\end{array}$ \\
\hline Observation & - $\quad$ The kick from the Sudr formation was slow and gradual and therefore made it hard to detect. \\
\hline
\end{tabular}

Table 6.8 Actual Field Case-6 Mud Cap Drilling

\begin{tabular}{|l|ll|}
\hline Case number & \multicolumn{2}{|c|}{ Case-6 } \\
\hline Well region of field & - & Elghwar field. \\
\hline $\begin{array}{l}\text { Open Hole Geological } \\
\text { Date }\end{array}$ & - & Arab-d reservoir manly limestone expected gain and complete loss. \\
\hline Well Data & - & Hole size 6-1/8". \\
& - & Hole depth 10500 ft MD. \\
& - & Last casing 7" casing shoe @ 7360 ft MD,6650 TVD. \\
& - & Horizontal well , length of horizontal section 3140 ft. \\
\hline Mud Data & - & $\begin{array}{l}\text { Had complete loss @ 8249. } \\
\text { Pump mud cap in annulus with } 11.5 \text { ppg \&with rate 2 bbl/min. } \\
\text { Operation Before Kick }\end{array}$ \\
\hline Well Control Event & - & Cont'd drilling operation with water and gel sweep. \\
\hline Action taken & - & Suddenly found the level close to surface. \\
\hline Observation & - & Shut-in well , SICP=SIDP=0 \\
& - & Well flowing due to mud cap weight wasn't enough. \\
& & Due to complete losses pressure couldn't build up while shut-In period \\
\hline
\end{tabular}


Table 6.9Actual Field Case-7\& Case-8 Human Effects.

\begin{tabular}{|c|c|c|}
\hline Case number & Case-7 & Case- 8 \\
\hline Well region of field & - $\quad$ Saudi arabia Elghwar field. & - $\quad$ Egyptian western desert. \\
\hline $\begin{array}{l}\text { Open Hole } \\
\text { Geological Date }\end{array}$ & $\begin{array}{ll}- & \text { Arab-c reservoir } \\
\text { - } & \text { Mainly limestone and streak of anhydrite }\end{array}$ & $\begin{array}{ll}- & \text { Work over well } \\
- & \text { ALAM EL BEWEB FM III D,E,G } \\
\text { - } & \text { Perforation mad on sand streak. } \\
\text { - } & \text { Tubing puncher above first packer. }\end{array}$ \\
\hline Well Data & $\begin{array}{ll}- & \text { Hole size 8.5". } \\
\text { - } & \text { Hole depth } 6067 \mathrm{ft} \mathrm{MD} . \\
- & \text { Last casing 9-5/8" @6429ft. } \\
\text { - } & \text { top of window@ } 5591 \mathrm{ft} \text { MD bottom of } \\
& \text { window } 5778 \mathrm{ft} .\end{array}$ & $\begin{array}{ll}\text { - } & \text { casing size } 9-5 / 8 " \\
\text { - } & \text { first packer @ } 9044 \mathrm{ft} \\
\text { - } & \text { second packer @9279 ft } \\
\text { - } & \text { perforation interval } \\
\text { - } & \text { AEB III D }(9,164-9,172 ') \\
\text { - } & \text { AEB III E }(9,206-9,216)^{\prime} \\
\text { - } & \text { AEB III E }(9,674-9,682)^{\prime} \\
\text { - } & \text { reservoir pressure } 3800 \mathrm{psi}\end{array}$ \\
\hline Mud Data & - $\quad 8.6$ ppg brine. & - $\quad 8.9$ ppg brine \\
\hline $\begin{array}{l}\text { Operation Before } \\
\text { Kick }\end{array}$ & $\begin{array}{l}\text { Driller was asked from directional } \\
\text { engineer to pick up the string but due to } \\
\text { misunderstanding driller slack-off to } \\
\text { 70klbs which lead to bit nozzle plug and } \\
\text { pressure increased to } 3000 \text { psi which cause } \\
\text { pump relief valve opened and leak } \\
\text { happened on pressure hose (connection } \\
\text { between stand pipe manifold and TDS). } \\
\text { Then they decided to Pull out of hole with } \\
\text { directional assembly to casing shoe while } \\
\text { fixing the problem then run in hole again } \\
\text { to bottom. }\end{array}$ & $\begin{array}{l}\text { Killing operation was planned by } \\
\text { bullheading with } 8.9 \text { ppg brine with } \\
\text { maximum well head pressure } 1,500 \text { psi, } \\
\text { observe well return at flare pit and } \\
\text { continue pumping till brine in-out same } \\
\text { ppg. } \\
\text { In case the maximum wellhead pressure is } \\
\text { reached before complete circulation of the } \\
\text { well, stop pumping till pressure decreased } \\
\text { to value ; repeat this operation till pump } \\
\text { all volume capacity. }\end{array}$ \\
\hline Well Control Event & $\begin{array}{l}\text { After reach to bottom the driller } \\
\text { performed flow check found slight return. }\end{array}$ & 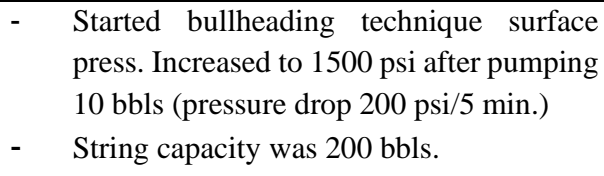 \\
\hline Action taken & 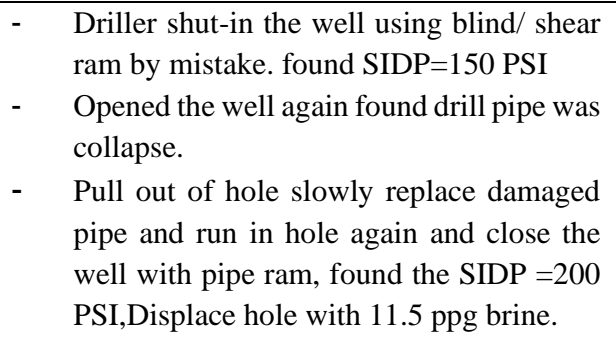 & $\begin{array}{l}\text { - } \quad \text { Killing the well by reverse circulation } \\
\text { technique by pumping } 900 \text { bbls. } \\
\text { - } \quad \text { The annulus capacity was } 720 \text { bbls. }\end{array}$ \\
\hline Observation & $\begin{array}{ll}- & \text { Lack of drilling experience. } \\
\text { - } & \text { Miscommunication between driller and } \\
\text { directional drilling }\end{array}$ & $\begin{array}{ll}\text { - } & \text { Bullheading not applicable this case. } \\
& \text { Cause loss time }+/-7 \text { hours } \\
\text { - } & \text { Sucker rod was parted and lost in hole and } \\
\text { hung on 2.81" x-nipple. }\end{array}$ \\
\hline
\end{tabular}


Table 6.10 Actual Field Case-9 Top Kill.

\begin{tabular}{|c|c|}
\hline Case number & Case-9 \\
\hline Well field & - $\quad$ Elghwar field. \\
\hline $\begin{array}{c}\text { Open Hole } \\
\text { Geological Date }\end{array}$ & $\begin{array}{l}\text { - } \quad \text { YAMAMA mainly limestone. } \\
\text { - } \quad \text { SULAIY limestone expected water flow. } \\
\text { - } \quad \text { HITH anhydrite with minor streaks of limestone and dolomite. } \\
\text { - } \quad \text { ARAB A mainly limestone, anhydrite. } \\
\text { - } \quad \text { ARAB B mainly limestone, anhydrite. } \\
\text { - } \quad \text { ARABC mainly limestone, anhydrite. }\end{array}$ \\
\hline Well Data & $\begin{array}{ll} & \text { Hole size } 8.5 " \\
\text { - } & \text { Hole depth } 8440 \mathrm{ft} \text { MD,TVD } 6999 \mathrm{ft} . \\
\text { - } \quad \text { Last casing 7" casing shoe @ 5647ft MD,5478 ft TVD }\end{array}$ \\
\hline Mud Data & - $\quad 10.3 \mathrm{ppg}$ oil base mud \\
\hline $\begin{array}{l}\text { Operation Before } \\
\text { Kick }\end{array}$ & $\begin{array}{l}\text { - } \quad \text { Finished drilling } 81 / 2 " \text { directional hole using mud motor with } 10.3 \mathrm{ppg} \text { oil base mud \& } 100 \% \\
\text { return to } 8440 \text { ' MD, } 6999 \text { TVD, Started pull out of hole with directional assembly using Pump } \\
\text { from } 8440 \text { ' to 5900'. }\end{array}$ \\
\hline Well Control Event & - $\quad$ Observed gain 7 bbls while trip, mud weight in and out was 10.3 ppg. \\
\hline Action taken & $\begin{array}{l}\text { - } \quad \text { Shut-in well, using hard shut-in procedures SIDP=130 psi SICP=130 psi, Increased mud weight } \\
\text { to } 10.6 \mathrm{ppg} \text { in active pit. Displace } 10.6 \mathrm{ppg} \text { to } 10.3 \mathrm{ppg} @ 5900 \mathrm{ft} \text { M.D. performed flow check } \\
\text { found well static ,opened the well and run in hole again to bottom and circulate complete cycle } \\
\text { to perform mud conditioning. }\end{array}$ \\
\hline Observation & $\begin{array}{l}\text { Hole wasn't in good condition. } \\
\text { - } \quad \text { Using top kill method to control off bottom kick. }\end{array}$ \\
\hline
\end{tabular}

